\title{
Finance and Development in Muslim Economies
}

\author{
M. Shahid Ebrahim ${ }^{1}$ • Philip Molyneux ${ }^{2}$ • \\ Steven Ongena ${ }^{3}$
}

Published online: 16 February 2017

(C) Springer Science+Business Media New York 2017

The recent trend in the Muslim world towards reinforcing their cultural (i.e., religious) values on their economic policies and institutions has resulted in a roughly $\$ 2$ trillion Islamic financial services industry. This industry is quite resilient and growing at a large rate even at a time when conventional banks were failing in the recent financial crisis.

Financial systems play a vital role in advancing intermediation by mitigating market frictions, facilitating efficient investment decisions, allocating scarce capital and conveying financial transactions. This, in turn, stimulates capital accumulation decisions and technological innovation that are crucial in delineating a nation's long-term economic path.

A conference was held in Bangor University, Gwynedd, North Wales on September 15, 2014, to critically examine the Islamic financial services industry under the aegis of Bangor University and the Islamic Research and Training Institute (IRTI) of the Islamic Development Bank. The four high-quality papers presented at the conference are featured in this Special Issue of the Journal of Financial Services Research (JFSR). They are categorized into two groups. The first group comprises of a paper studying moral obligations and a firm's engagement in ethical activities. The remaining three papers study the risk of Islamic banks vis-à-vis conventional banks. These are described below.

\section{Ethical principles and earnings quality of a firm}

Alsaadi et al. (2017) empirically investigate the impact of Corporate Social Responsibility (CSR) and Shariah compliance on earnings quality in their paper on "Corporate Social Responsibility, Shariah-Compliance and Earnings Quality". Their data includes firms from ten European countries over 2003 to 2013. Their results illustrate that firms displaying a high

M. Shahid Ebrahim

m.s.ebrahim@durham.ac.uk

1 Durham University Business School, Durham, UK

2 Bangor Business School, Bangor, Gwynedd, UK

3 University of Zurich, IBF, Plattenstrasse 14, CH-8032 Zürich, Switzerland 
level of CSR are less likely to engage in earnings manipulation. In contrast, firms in compliance with the Shariah are more likely to manage earnings. They rationalize their controversial result by stating that inclusion of a firm in the index implies that they do not do anything prohibited in Islam. In other words, membership does not play a crucial role in ethical behavior as the Shariah index comprises of firms based on negative screening instead of social welfare and transparency.

\subsection{Contrasting risk-taking by islamic banks with their conventional counterparts}

The three papers in this area seem to be inspired by Abedifar et al. (2013) and study various facets of risk of Islamic banks. The paper by Mollah et al. (2017) on "The governance, risk-taking and performance of Islamic banks" studies the impact of governance structures on the risk-taking and overall performance of Islamic banks in contrast to conventional ones. Their empirical investigation, using hand-collected data from fiftytwo Islamic banks and one-hundred and four conventional ones in fourteen countries for the period 2005 to 2013, attributes the high risk-taking (and thus better financial performance) of Islamic banks (in contrast to conventional ones) on their governance structures. This result is observed despite cross-country variation and the common perception of Islamic banks' conservativeness. Nonetheless, Islamic banks are capitalized better than conventional ones.

The above result leads one to question the failure risk of Islamic banks with respect to their conventional counterparts. This issue is analyzed by Pappas et al. (2017) in their paper on " $A$ survival analysis of Islamic and conventional banks". These authors employ a novel approach to survival analysis by incorporating the Cox proportional hazard model to a data set comprising of four hundred and twenty-one banks in twenty Middle and Far Eastern countries from 1995 to 2010. They realize that Islamic banks have a significantly lower failure rate in contrast to their conventional counterparts. The reduced risk is found both unconditionally and conditionally on microeconomic (bank-related) as well as macroeconomic and market structure variables.

The above result illustrates that the financial system safety net (i.e., deposit insurance) is contingent on the unique risk profile of Islamic versus conventional banks. This issue is studied by Aysan et al. (2017) in their paper titled "Islamic banks, deposit insurance reform and market discipline: Evidence from a natural framework". The authors study this issue empirically in the context of Turkey, which reformed its deposit insurance scheme to cover both Islamic as well as conventional banks. The purpose of the study is to examine whether Islamic and/or conventional banks are subject to market discipline or not. Their findings highlight the distinct response of depositors to both types of banks. The authors realize that in the pre-deposit insurance reform period, the depositors of conventional banks were more concerned about bank risk in contrast to those of Islamic banks. This reverses in the postreform period. The authors interpret this as implying that the reform: (i) has changed the sensitivities of religious depositors; and (ii) ceased the mutual supervision and support amongst Islamic banks. This leads the authors to conclude that the earlier Islamic deposit insurance had a 'numbing effect on market discipline'.

To sum up, we believe that the collection of papers in this Special Issue makes a great contribution to the understanding of the Islamic financial services industry. The insightful results and new findings can help in the structuring of appropriate regulatory framework and improving policy making. 
Acknowledgments We would like to thank the editor, Haluk Unal, for providing us the opportunity to guestedit this Special Issue of the Journal of Financial Services Research. We are also grateful to Muhammad Azmi Omar and Turkhan Ali Manap from the Islamic Research and Training Institute of the Islamic Development Bank for their financial support of the conference and to anonymous reviewers for their rigorous referee reports.

\section{Reference}

Abedifar P, Molyneux P, Tarazi A (2013) Risks in Islamic banking. Review of Finance 17:1-62

Alsaadi A, Ebrahim M S, Jaafar A (2017) Corporate social responsibility, Shariah-compliance and earnings quality. J Financ Serv Res. doi:10.1007/s10693-016-0263-0

Aysan A F, Disli M, Duygun M, Özturk H (2017) Islamic banks, deposit insurance reform and market discipline: evidence from a natural framework. J Financ Serv Res. doi:10.1007/s10693-016-0248-Z

Mollah S, Hassan M K, Al Farooque O, Mobarek A (2017) The governance, risk-taking and performance of Islamic banks. J Financ Serv Res. doi:10.1007/s10693-016-0245-2

Pappas V, Ongena S, Izzeldin M, Fuertes A M (2017) A survival analysis of Islamic and conventional banks. J Financ Serv Res. doi:10.1007/s10693-016-0239-0 